This article was downloaded by: [DEFF]

On: 13 November 2008

Access details: Access Details: [subscription number 789685089]

Publisher Taylor \& Francis

Informa Ltd Registered in England and Wales Registered Number: 1072954 Registered office: Mortimer House, 37-41 Mortimer Street, London W1T 3JH, UK

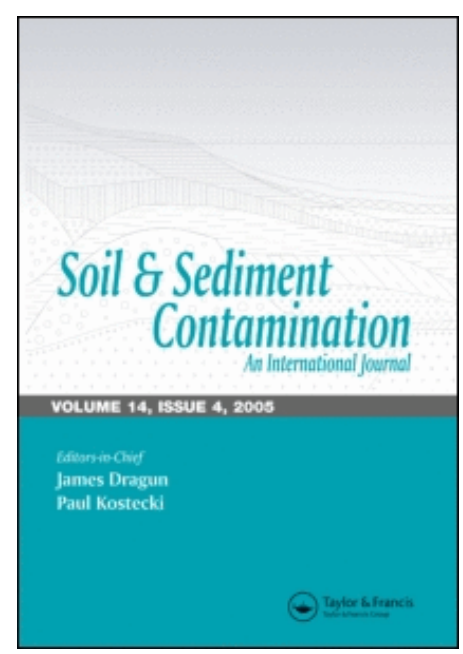

Soil and Sediment Contamination: An International Journal

Publication details, including instructions for authors and subscription information: http://www.informaworld.com/smpp/title content=t713401148

\title{
Germination and Growth of Selected Plants in a Petroleum Contaminated Calcareous Soil
}

A. Besalatpour a; A. H. Khoshgoftarmanesh a; M. A. Hajabbasi a; M. Afyuni a

a Department of Soil Science, College of Agriculture, Isfahan University of Technology, Isfahan, Iran

Online Publication Date: 01 November 2008

To cite this Article Besalatpour, A., Khoshgoftarmanesh, A. H., Hajabbasi, M. A. and Afyuni, M.(2008)'Germination and Growth of Selected Plants in a Petroleum Contaminated Calcareous Soil',Soil and Sediment Contamination: An International Journal,17:6,665 $-676$

To link to this Article: DOI: $10.1080 / 15320380802425113$

URL: http://dx.doi.org/10.1080/15320380802425113

\section{PLEASE SCROLL DOWN FOR ARTICLE}

\footnotetext{
Full terms and conditions of use: http://www.informaworld.com/terms-and-conditions-of-access.pdf

This article may be used for research, teaching and private study purposes. Any substantial or systematic reproduction, re-distribution, re-selling, loan or sub-licensing, systematic supply or distribution in any form to anyone is expressly forbidden.

The publisher does not give any warranty express or implied or make any representation that the contents will be complete or accurate or up to date. The accuracy of any instructions, formulae and drug doses should be independently verified with primary sources. The publisher shall not be liable for any loss, actions, claims, proceedings, demand or costs or damages whatsoever or howsoever caused arising directly or indirectly in connection with or arising out of the use of this material.
} 


\title{
Germination and Growth of Selected Plants in a Petroleum Contaminated Calcareous Soil
}

\author{
A. BESALATPOUR, A.H. KHOSHGOFTARMANESH, \\ M. A. HAJABBASI, AND M. AFYUNI \\ Department of Soil Science, College of Agriculture, Isfahan University of \\ Technology, Isfahan, Iran
}

\begin{abstract}
Difference in the ability of various crops to germinate and grow in contaminated soils should be better explored to choose the most appropriate plant species in the development of any phytoremediation process. Germination and subsequent growth of seven plants including tall fescue, agropyron, puccinellia, white clover, canola, safflower, and sunflower were tested in a soil with three petroleum contamination levels. Treatments consisted of CO (uncontaminated soil), C1 (1:1 w/w, uncontaminated: contaminated soil), and $C 2$ (1:3 w/w, uncontaminated: contaminated soil). Presence of total petroleum hydrocarbons (TPHs) in the soil had no effect on seed germination of agropyron, white clover, sunflower, and safflower, although canola and white clover seedlings were sensitive to these contaminants and failed to produce dry matter yield (DMY) at the end of the trial period. There were 52 and 56\% decrease in germination of tall fescue and puccinellia seeds, respectively, in $C 2$ treatment as compared to $C 0$ treatment. No reduction was found in DMY of puccinellia in contaminated soils (C1 and C2), while the presence of TPHs in C2 decreased DMY of sunflower and safflower by about 50 and $73 \%$, respectively. The results showed that germination did not predict the crop differences in subsequent growth and cannot be used as an approach to find suitable crops for field trials.
\end{abstract}

Keywords phytoremediation, germination, subsequent growth, total petroleum hydrocarbons (TPHs), calcareous soil

\section{Introduction}

Total petroleum hydrocarbons (TPHs) are important sources of soil and environmental pollution around oil refineries. Soil becomes contaminated with petroleum hydrocarbon through accidents, transportation, and leakage from tanks and pipeline ruptures (Nicolotti and Eglis, 1998). Presence of petroleum hydrocarbons in soils may be toxic to humans, plants, and soil microorganisms and act as a source of groundwater contamination (Siddiqui and Adams, 2001). Some genotoxic effects of these pollutants have been documented (Bjorseth et al., 1979; Gunther and Jones, 1988; Haeseler et al., 1999; Gao and Zhu, 2004). Therefore, there is serious concern about the environmental presence of TPHs, especially their potential for bioaccumulation in food chains (Morehead et al., 1986; Nylund et al., 1992; Fujikawa et al., 1993; Jian et al., 2004).

Remediation of old industrial sites is a necessary step in order to meet the demand for urban housing, office, and leisure spaces. Decreasing the concentration of these potentially

Address correspondence to A. H. Khoshgoftarmanesh, Department of Soil Sciences, College of Agriculture, University of Technology, Isfahan, Iran 84154. E-mail: amirhkhosh@cc.iut.ac.ir 
toxic compounds is also beneficial to the environment. Many methods, including removal, incineration and removal followed by thermal desorption, have been used for the cleanup of TPH-contaminated soils, although all these methods are cost-prohibitive (Joner and Leyval, 2001). To find more environmentally and economically acceptable options, biological methods such as phytoremediation have been investigated.

Phytoremediation has long been recognized as a cost-effective method for removal of these pollutants from soil (Aprill and Sims, 1990). Phytoremediation or the use of living green plants in-situ to "clean up" land is a low input approach that depends on natural attenuation by biodegradation and physiochemical mechanisms that decreases the pollutant concentration where sowing plants may be the only intervention (Joner and Leyval, 2001).

The ultimate aim of planting in TPH-contaminated soil is to break down and remove the TPH by a combination of mechanisms of plant and soil interactions, such as improvement of physical and chemical properties of a contaminated soil, increase in soil microbial activity, and increase in contact between rhizosphere microbes and the toxic compounds in a contaminated soil (Aprill and Sims, 1990). In addition, the "greening" of a site confers other important benefits on a contaminated site, such as protection against wind erosion, reduction of surface water run-off, reinforcement of soil by roots (Harris et al., 1996). It also enhances the area, making it aesthetically more pleasing.

To achieve maximum TPH and polycyclic aromatic hydrocarbon (PAH) reduction and to successfully establish stable vegetation cover, various criteria must be considered. The plants should be chosen carefully so that they provide a maximum root surface area (Aprill and Sims, 1990) and preferably be native to the area. Due to the frequently poor nutrient availability in contaminated sites and by considering that cost is an important factor, plants that require little attention (e.g., fertilizers and frequent cutting) are preferable (Harris et al., 1996).

Grasses have been used in remediation of contaminated soils due to their fibrous root systems with extensive surface area for microbial colonization. The fibrous root system forms a continuous, dense rhizosphere that provides ideal conditions for phytoremediation (Adam et al., 2002). Nitrogen-fixing plants such as legumes have also been used to remediate contaminated soils as nitrogen is frequently the limiting nutrient for mineralizing organic contaminants in soil. Organic contaminants, such as petroleum hydrocarbons, stimulate microbial activities by the added carbon and as a result cause an imbalance in the soil $\mathrm{C}: \mathrm{N}$ ratio, which may result in immobilization of soil nitrogen by the microbial biomass. Accordingly, legumes that are able to fix atmospheric $\mathrm{N}_{2}$ may prove more successful at growing on PAH-contaminated soil (Gudin and Syratt, 1975).

Considering the cost of more extensive testing, germination tests have frequently been used in selecting species to be grown on contaminated sites. Previously, research work has reported the adverse effects of PAH and TPH on germination but many of these trials involved freshly contaminated soils or subjecting the seeds to solutions of the PAHs (Chal neau et al., 1997; Henner et al., 1999; Ren et al., 1996; Smreczak and MaliszewskaKordybach, 2003).

There are several petroleum refineries in Iran, such as the Tehran oil refinery. Unfortunately, environmental pollution is increasingly becoming a great concern in these regions, so that in some parts ecosystem is subject to serious challenges. Different approaches to reduce this problem have failed so far, but it appears that phytoremediation might be suitable to reduce environmental hazards of petroleum hydrocarbons around the Tehran oil refinery.

The objectives of this study were to compare the ability of selected plant genotypes, including two grasses, a legume and four crops, to germinate and grow in petroleumcontaminated soils. Furthermore, using germination rate as an indicator of subsequent 
establishment and growth of these plants in contaminated soils was investigated. The most successful plant genotypes would then be used in subsequent phytoremediation studies.

\section{Materials and Methods}

\section{Soil Preparation}

Bulk samples $(300 \mathrm{~kg})$ of uncontaminated and petroleum-contaminated surface $(0-40 \mathrm{~cm})$ soils were collected from farm land and oily waste landfills around the Tehran oil refinery. Soils were air dried and passed through a 4-mm sieve. Three contamination levels were prepared by mixing uncontaminated (farm soil) and contaminated soils (oily waste landfill soil) in different weight ratios. Contamination treatments consisted of $\mathrm{C} 0$ (uncontaminated soil), C1 (1:1 w/w, uncontaminated: contaminated soil) and C2 (1:3 w/w, uncontaminated: contaminated soil). The samples were landfarmed and mixed at intervals every 3 days by a garden hoe to ensure a homogenous distribution of the petroleum pollutants.

\section{Soil Characteristics}

Selected physical and chemical properties of the uncontaminated and contaminated soil samples are shown in Table 1. Soil pH was measured using a digital pH-meter (Model 691, Metrohm AG Herisau Switzerland) (Thomas, 1996) and electrical conductivity (ECe) using an EC-meter (Model Ohm-644, Metrohm AG Herisau Switzerland) (Rhoades, 1996). Organic matter content was determined by the Walkley-Black method (Nelson and Sommers, 1982). The $\mathrm{CaCO}_{3}$ equivalent was determined by neutralizing with $\mathrm{HCl}$ and back titration with $\mathrm{NaOH}$ (Black et al., 1965). Available-P content was extracted from the soil with $0.5 \mathrm{M}$ $\mathrm{NaHCO}_{3}($ Olsen and Sommers, 1982) and was determined by a colorimetric method (Black et al., 1965). Chelate-extractable $\mathrm{Zn}, \mathrm{Fe}, \mathrm{Mn}, \mathrm{Cu}$, was extracted using DTPA as described

\section{Table 1}

Selected physical and chemical properties of soils sampled from farm land and oily waste landfill

\begin{tabular}{lcc}
\hline Characteristic & Farm land soil & $\begin{array}{c}\text { Oily waste } \\
\text { landfill soil }\end{array}$ \\
\hline Clay $(\%)$ & 26 & 22 \\
pH & 7.8 & 6.9 \\
$\mathrm{ECe}\left(\mathrm{dS} \mathrm{m}^{-1}\right)$ & 7.4 & 9.8 \\
Organic matter (\%) & 0.99 & 10.23 \\
Total N (\%) & 0.08 & 1.22 \\
$\mathrm{CaCO}_{3}$, equivalent (\%) & 29.5 & 24.5 \\
Available-P $\left(\mathrm{mg} \mathrm{kg}^{-1}\right)$ & 45.0 & 150.0 \\
Available-K (mg kg & 44.8 \\
DTPA-Mn $\left(\mathrm{mg} \mathrm{kg}^{-1}\right)$ & 21.5 & 39.3 \\
DTPA-Zn $\left(\mathrm{mg} \mathrm{kg}^{-1}\right)$ & 18.0 & 12.03 \\
DTPA-Cu $\left(\mathrm{mg} \mathrm{kg}^{-1}\right)$ & 18.51 & 89.1 \\
DTPA-Fe $\left(\mathrm{mg} \mathrm{kg}^{-1}\right)$ & 5.4 & 62.4 \\
DTPA-Ni $\left(\mathrm{mg} \mathrm{kg}^{-1}\right)$ & 14.7 & 2.76 \\
\hline
\end{tabular}


Table 2

Concentrations of measured selected PAHs and TPHs in oily waste landfill soil

\begin{tabular}{lc}
\hline PAH & $\mathrm{mg} \mathrm{kg}^{-1}$ \\
\hline Naphthalene & 42.0 \\
Phenanthrene & 31.7 \\
Anthracene & 2.8 \\
Fluoranthene & 26.7 \\
Pyrene & 18.3 \\
Benzo[k]fluoranthene & 0.2 \\
Benz[a] pyrene & 0.4 \\
Benzo[g,h,i]perylene & 7.0 \\
TPH & 102586 \\
\hline
\end{tabular}

by Lindsay and Norvell (1978) and then determined using atomic absorption spectrometry (AAS) (Perkin Elmer 3400, Perkin-Elmer, Wellesley, MA). Total N was determined by the micro-Kjeldahl method (Bremner and Mulvaney, 1982).

\section{TPHs and PAHs Analysis}

The TPHs and selected PAHs in the contaminated treatments was extracted from $30 \mathrm{~g}$ soil subsamples by Soxhlet using a 1:1 (v/v) dichloromethane and $\mathrm{n}$-hexane $(150 \mathrm{ml})$ mixture for $24 \mathrm{~h}$ (Christopher et al., 1988). Concentration of TPHs and selected PAHs were determined in soil extracts using gas-chromatography (GC) with a Delsi DI 200 chromatograph equipped with a direct injection port and FID detector both set at $340 \mathrm{C}^{\circ}$; carrier gas was helium under $0.08 \mathrm{MPa}$; column was a CP Sil $5 \mathrm{CB}$ (Chrompack) capillary column (50 m by 0.32 $\mathrm{mm}$, film thickness $0.25 \mu \mathrm{m}$ ); temperature program was 100 to $320 \mathrm{C}^{o}$, at $3 \mathrm{C}^{o} \mathrm{~min}^{-1}$. Concentrations of TPHs and selected PAHs in oily waste landfill soil are shown in Table 2. In addition, the TPHs concentrations in different contamination treatments are shown in Table 3.

\section{Greenhouse Experiment}

Seven plants including; tall fescue (Festuca arundiacea L.), Agropyron (Agropyron smithi L.), Puccinellia (Puccinellia distance L.), white clover (Trifolium repens L.), canola (Brassica napus L.), safflower(Carthamus tinctorius L.) and sunflower (Heliantus annus L.) were tested. About $1 \mathrm{~kg}$ of soil samples was added to plastic pots having $75 \mathrm{~mm}$ diameter

Table 3

Concentrations of measured TPHs in different contamination treatments

\begin{tabular}{lr}
\hline Treatment & $\mathrm{mg} \mathrm{kg}^{-1}$ \\
\hline C0 & $<50$ \\
C1 & 40366 \\
C2 & 69767 \\
\hline
\end{tabular}


and $150 \mathrm{~mm}$ height. A disc of filter paper was placed at the bottom of each pot to prevent soil escaping from the drainage holes. Seeds of the plants were planted 1 to $2 \mathrm{~cm}$ deep in the pots. The plants were watered from the top during the germination period so that soil moisture was kept near $70 \%$ field capacity. Germination was monitored closely over the first two weeks of the trials. The number of germinated seeds in each pot was recorded and expressed as a percentage of the number of seeds added. Germination rate was derived by taking the germination count at daily intervals up to 14 days and computed according to the method proposed by Maguire (1962).

In each trial, the plants were grown for 8 weeks after germination period in the greenhouse. The minimum and maximum temperature was 22 and $37 \mathrm{C}^{\circ}$, respectively. Plant height from the base to leaf tip of the longest leaf was measured at 3-day intervals. At the end of each growing trial, the plants (shoot plus root) were harvested, washed with deionized water, dried in an oven at $80 \mathrm{C}^{\circ}$ for $48 \mathrm{~h}$ and then weighed.

\section{Data Analysis}

The split plots experiment with completely randomized design in triplicates was conducted. Results were analyzed by Analysis of Variance using the SAS computer program (SAS Institute, 1988).

\section{Result and Discussion}

\section{Germination Percentage and Rate}

The effect of petroleum contamination on germination percentage of the studied plant genotypes is shown in Fig. 1. The presence of TPHs in both contamination treatments had no significant $(\mathrm{P}<0.05)$ effect on germination percentage of agropyron, sunflower, safflower, and clover (Table 4). Also, there were no significant differences $(\mathrm{P}<0.05)$ in seed germination percentage of canola between $\mathrm{C} 1$ treatment with control during of the experimental period (Table. 4). In contrast, seed germination of tall fescue and puccinellia was significantly $(\mathrm{P}<0.05)$ decreased in $\mathrm{C} 1$ and $\mathrm{C} 2$ treatments compared to the $\mathrm{C} 0$; however, there were no significant differences $(\mathrm{P}<0.05)$ in seed germination percentage of tall fescue between soil $\mathrm{C} 1$ with $\mathrm{C} 2$ treatments. There were $52 \%$ and $56 \%$ decreases in germination of tall fescue and puccinellia seeds in $\mathrm{C} 2$ treatment as compared to $\mathrm{C} 0$ at the end of experimental period, respectively (Fig. 1). It seems that petroleum hydrocarbons have an indirect effect on the ability of the soil to provide water and nutrients to the seed for germination and subsequent growth of plants (Reilly et al., 1996), and as a result, inhibits seed germination as compared with $\mathrm{C} 0$ treatment. Also, this inhibitory effect on germination may be attributed to the physical constraints induced by petroleum hydrocarbons remaining in the soil on the seed (Adam and Duncan, 2002). Furthermore, it seems that seed resistance to phytotoxic properties of oils is mainly attributed to the structure of the cell wall (Terje, 1984).

Significant variation was found in seed germination rate among studied genotypes (Fig. 2). The presence of petroleum contamination in both $\mathrm{C} 1$ and $\mathrm{C} 2$ treatments significantly $(\mathrm{P}<0.05)$ decreased germination rate of puccinellia and tall fescue; however, there was no significant difference between $\mathrm{C} 1$ and $\mathrm{C} 2$ treatments for tall fescue (Fig. 2). Seed germination of puccinellia started with 4 and 5 day delay in $\mathrm{C} 1$ and $\mathrm{C} 2$ treatments, respectively (Fig. 1). A 3-day delay in tall fescue seed germination was observed (Fig. 2). Germination 

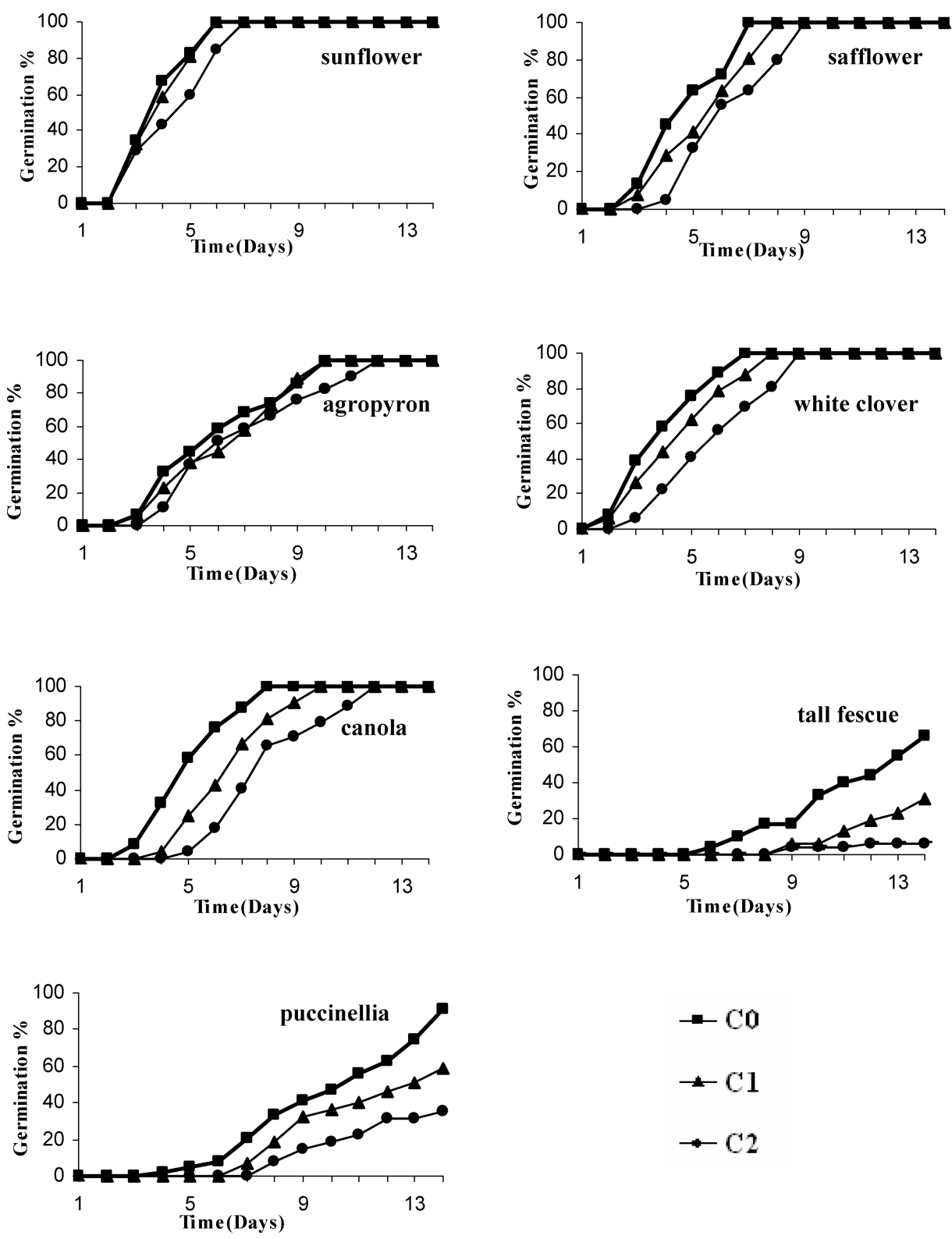

Figure 1. Seed germination of plant genotypes in soils with different petroleum contamination levels, C0 (uncontaminated soil), C1 (1:1 w/w, uncontaminated: contaminated soil) and C2 (1:3 w/w, uncontaminated: contaminated soil).

rate of canola decreased at the higher contamination level (C2), but no decrease was found at the $\mathrm{C} 1$ treatment as compared to the $\mathrm{C} 0$ treatment. According to Adam and Duncan (2002), petroleum hydrocarbons can cause a film of oil to form around the seed, which would act as a physical barrier, preventing or reducing both water and oxygen transfer to the seed. This physical impedance was shown to delay seed emergence, and therefore could be an additional factor in the overall inhibitory effect of petroleum hydrocarbons contamination 
Table 4

Average percentage seed germination of plant genotypes in soils with different petroleum contamination levels

\begin{tabular}{lccc}
\hline & \multicolumn{3}{c}{ Percentage of seeds germinated } \\
\cline { 2 - 4 } Plant genotype & \multicolumn{1}{c}{$\mathrm{C}_{0}$} & $\mathrm{C}_{1}$ & $\mathrm{C}_{2}$ \\
\hline Sunflower & $89.45^{a *}$ & $89.12^{a}$ & $86.53^{a}$ \\
Safflower & $86^{a}$ & $76^{a}$ & $72.7^{a}$ \\
Clover & $77.6^{a}$ & $69.3^{a}$ & $61.3^{a}$ \\
Agropyron & $72.7^{a}$ & $68.8^{a}$ & $63.8^{a}$ \\
Canola & $84.5^{a}$ & $73.7^{a}$ & $65^{b}$ \\
Tall fescue & $14.74^{a}$ & $2^{b}$ & $0.89^{b}$ \\
Puccinellia & $23.5^{a}$ & $12.89^{b}$ & $6.85^{c}$ \\
\hline
\end{tabular}

*In each row, means with the same letters are not significantly different at $\mathrm{P}<0.05$.

on germination (Adam et al., 2002). In contrast, no such inhibitory effect or delay was found in germination rate of agropyron, sunflower, clover and safflower in the petroleum contamination treatments (Fig. 2).

In other studies, genotypic variations in seed germination rate and percentage have been reported previously (Crafts and Reiber, 1948; Currier, 1951; Baker, 1970; Warner et al., 1983; Gauvrit and Cabanne, 1993; Chal neau et al., 1997). For example, Gauvrit and Cabanne (1993) found that the members of the family Umbelliferae (e.g., carrots) are notably tolerant to injury by lighter oils (low molecular weight) whereas grasses are intolerant. Maila and Cloete (2002) concluded that increasing concentration of PAHs by $50 \mathrm{mg} \mathrm{kg}^{-1}$ to $1000 \mathrm{mg} \mathrm{kg}^{-1}$ decreased germination of L. sativum about 75 and $16 \%$, respectively, in the artificially contaminated soil. Also, Chal neau et al. (1997) observed significant dose-dependent reductions in the germination rate in all their investigated plant species and reported that the resistance of seeds to the oil hydrocarbons contaminants in the soils followed the order of sunflower $>$ bean $>$ wheat $>$ clover $>$ maize $>$ barley $>$ lettuce. According to the findings of Adam and Duncan (2002), the volatile fraction of diesel fuel plays an influential role in delaying seed emergence and reducing germination percentage; however, seed germination response varied greatly with plant species and was species specific, as members of the same plant family showed differential sensitivity to diesel fuel contamination.

\section{Subsequent Growth and Total Dry Matter Yield}

Subsequent growth of plant genotypes for an eight-week experimental period is shown in Figure 3. Plant height was significantly $(\mathrm{P}<0.05)$ reduced by the presence of TPHs in all contamination treatments, especially in the higher TPH-concentration treatment. There was a significant $(\mathrm{P}<0.05)$ reduction in the height and shoot biomass of sunflower, safflower and agropyron in contamination treatments, although no significant difference was found between $\mathrm{C} 1$ and $\mathrm{C} 0$ treatments for agropyron (Fig. 3). On the other hand, the petroleum contamination had no effect on the height and shoot biomass of puccinellia (Fig. 3). In contrast, the height and shoot biomass of tall fescue significantly $(\mathrm{P}<0.05)$ decreased at $\mathrm{C} 1$ treatment. The inhibition of plant growth may be attributed to the inherent toxicity 

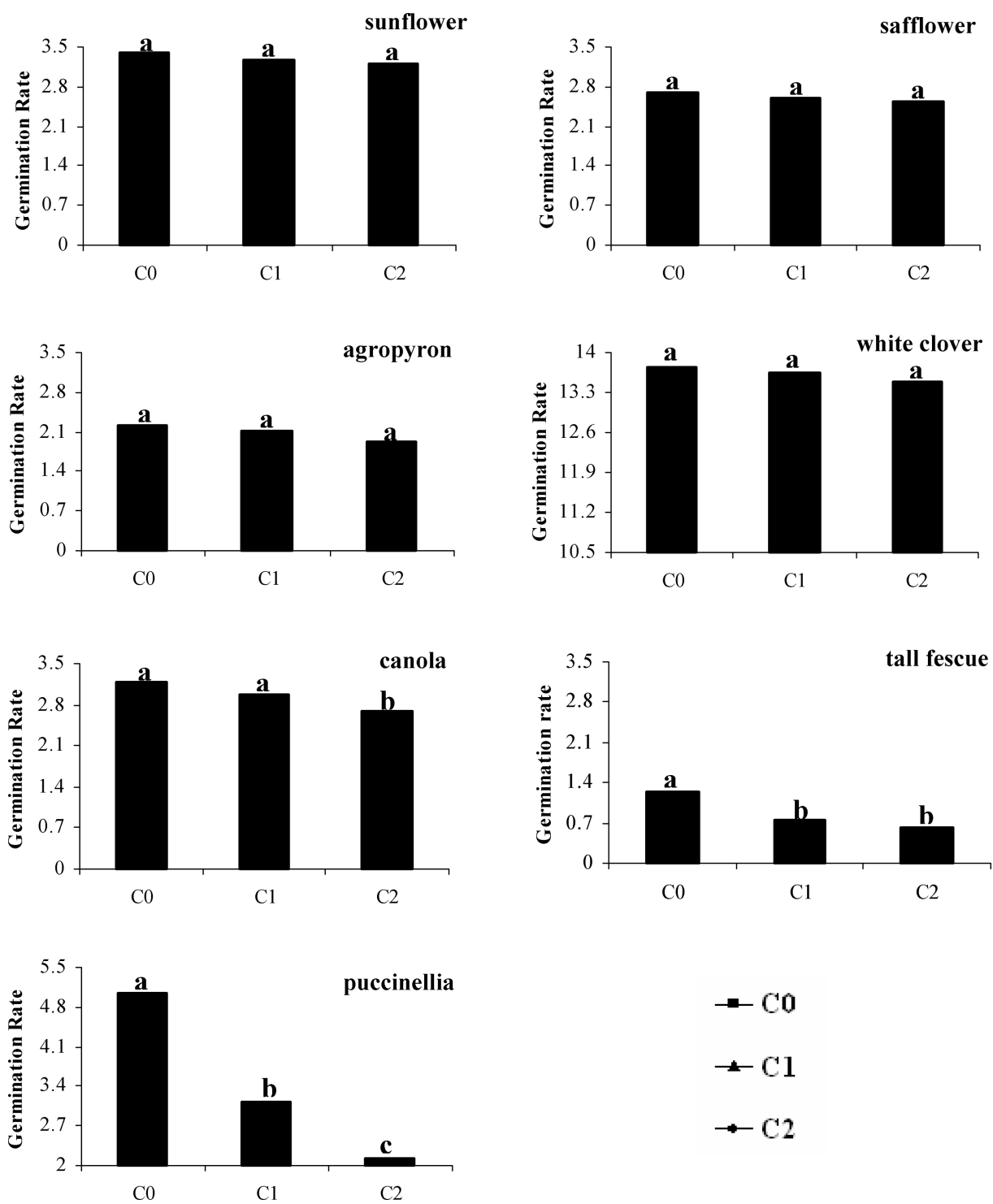

Figure 2. Seed germination rate of plant genotypes in soils with different petroleum contamination levels, C0 (uncontaminated soil), C1 (1:1 w/w, uncontaminated: contaminated soil) and C2 (1:3 w/w, uncontaminated: contaminated soil). Means with the same letter are not significantly different at $\mathrm{P}<$ 0.05 .

of TPHs, which results in dry matter yield (DMY) reduction (Bossert and Bartha, 1985; Chal neau et al., 1997).

With increasing concentration of the TPHs in the soil, DMY decreased significantly for all plants studied, except puccinellia (Table 5). Although, the canola and white clover seeds germinated well in the petroleum-contaminated soils (Fig. 1), their seedlings were sensitive to the contaminant compounds and did not survive. Therefore, no DMY was obtained at the end of trial period (Table 5). The presence of TPHs proportional to the contamination 
Table 5

Total dry matter yield of different plant genotypes grown in soils with different petroleum contamination levels for 8 weeks

\begin{tabular}{lccc}
\hline & \multicolumn{2}{c}{ Dry Matter Weight $\left(\mathrm{mg} \mathrm{pot}^{-1}\right)$} & \\
\cline { 2 - 3 } Plant genotype & $\mathrm{C}_{0}$ & $\mathrm{C}_{1}$ & $\mathrm{C}_{2}$ \\
\hline Sunflower & $2875^{a *}$ & $2121^{b}$ & $1457^{c}$ \\
Safflower & $974^{a}$ & $585^{b}$ & $264^{c}$ \\
Canola & $565^{a}$ & $\mathrm{np}^{b}$ & $\mathrm{np}^{b}$ \\
Clover & $437^{a}$ & $\mathrm{np}^{b}$ & $\mathrm{np}^{b}$ \\
Agropyron & $1221^{a}$ & $931^{a}$ & $601^{b}$ \\
Tall fescue & $856^{a}$ & $649^{a}$ & $283^{b}$ \\
Puccinellia & $641^{a}$ & $589^{a}$ & $487^{a}$ \\
\hline
\end{tabular}

\footnotetext{
${ }^{*}$ In each row, means with the same letters are not significantly different at $\mathrm{P}<0.05$.

"np" indicates no dry matter yielded at the end of experiment.
}

level reduced the total dry matter yield of sunflower and safflower. There were 60 and $73 \%$ decreases in DMY of safflower and 27 and 50\% decreases in DMY of sunflower in $\mathrm{C} 1$ and $\mathrm{C} 2$ treatments, respectively, as compared to the control (Table 5). A significant reduction in dry matter yield of tall fescue and agropyron was found in $\mathrm{C} 2$ but not $\mathrm{C} 1$ as compared to the control (Table 5). The wettability of oil-treated soil can be reduced by the hydrophobic properties of the contaminant crude oil, bringing about perturbations in the root development (Amakiri and Onofeghara, 1983) and reduction of water and nutrient availability to the crop (Bossert and Bartha, 1985; Terje, 1984). As a result, reduction in DMY of the studied plant genotypes may be attributed to both the inherent toxicity of TPHs and induced nutrient deficiencies. Puccinellia seedlings were tolerant to TPHs and no significant reduction was found in the total dry matter yield of this genotype in contaminated soils (Table 5).

The results showed that seeds of sunflower, safflower, clover, and canola germinated well in the petroleum contaminated soils ( $\mathrm{C} 1$ and $\mathrm{C} 2$ treatments), but their subsequent growth and dry matter yield was significantly reduced in the presence of TPHs (Fig. 1 and Table 5). Accordingly, these genotypes do not seem to be suitable for subsequent testing in field trials and reclamation of the investigated contaminated site by phytoremediation. In contrast, tall fescue and puccinellia had low seed germination percentage and rate in petroleum contaminated soils (Figs. 1 and 2), but their seedlings were tolerant to these compounds and lower reduction was found in their growth and dry matter yield as compared to the control (Fig. 3 and Table 5). This result suggests that tall fescue, agropyron and puccinellia are suitable for phytoremediation testing in field trials for the studied region.

Chal neau et al. (1997) reported that poor germination of seeds is related to the subsequent poor growth in freshly hydrocarbon-contaminated soil and concluded that the inhibition of plant growth increases with hydrocarbon concentration, but was not proportional to the loading rate. Furthermore, a reduction in biomass greater than $80 \%$ was found for wheat and bean at a concentration of $0.3 \%$ and lower than $30 \%$ for maize at $1.2 \%$. In contrast, Li et al. (1997) reported that oil contamination had no effect on seed germination of the plant studied while subsequent growth was significantly reduced. This controversy in the results may be attributed to different experimental conditions employed (e.g., PAHs 

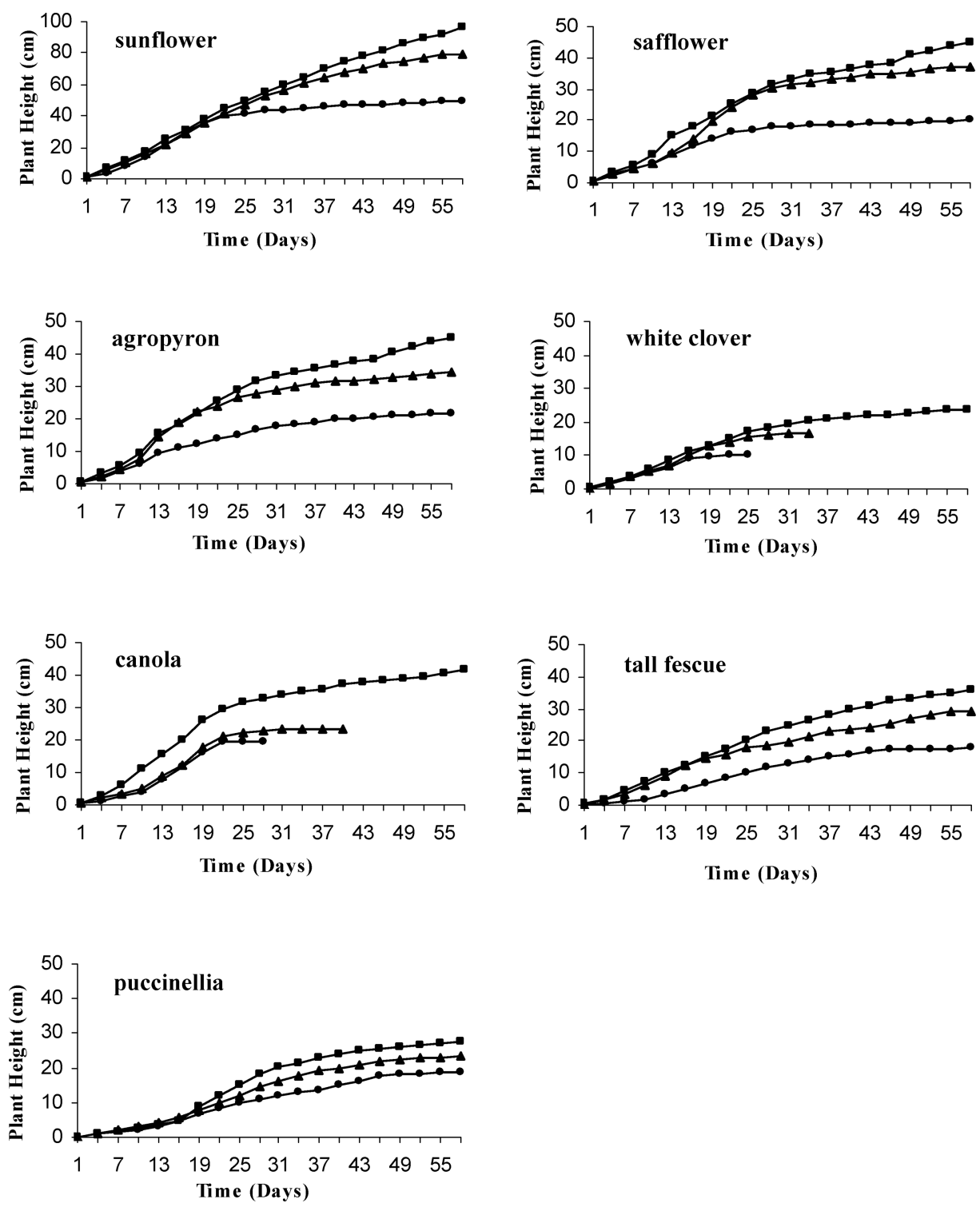

Figure 3. The height of plant genotypes in soils with different petroleum contamination levels, $\mathrm{C} 0$ (uncontaminated soil), C1 (1:1 w/w, uncontaminated: contaminated soil) and C2 (1:3 w/w, uncontaminated: contaminated soil).

solutions, freshly spiked soils and aged soils in closed or open systems) influencing PAHs availability and volatile losses.

\section{Conclusion}

The plant genotypes in our experiment showed different responses in seed germination and seedling growth to soil contamination treatments. The crops and legumes germinated well 
but thereafter grew poorly. While the grasses had poor seed germination, subsequent growth and establishment in the contaminated soils indicate amenability to phytoremediation. Furthermore, the results showed that germination testing alone cannot be used as an approach to find out suitable plant species for subsequent testing in field trials.

\section{References}

Adam, G., and Duncan, H. 2002. Influence of diesel fuel on seed germination. J. Environ. Pollut. 120, 363-370.

Adam, G., Gamon, K., Morris, D.G., and Duncan, H. 2002. Effect of alcohol on the movement of petroleum hydrocarbon fuels in soil. J. Sci. Total Environ. 286, (1-3), 15-25.

Amakiri, J.O., and Onofeghara. F.A. 1983. Effect of crud oil pollution on the germination of Zea mays and Abelmoshus esculentus and Capsicum frutescens. J. Environ. Pollut 35, 159-67.

Aprill, W., and Sims, R.C. 1990. Evaluation of the use of prairie grasses for stimulating polycyclic aromatic hydrocarbon treatment in soil. Chemosphere. 20, 253-265.

Baker, J.M. 1970. The effects of oils on plants. J. Environ. Pollut. 1, $27-44$.

Bjorseth, A., Lunde, G., and Lindskog, A., 1979. Long-range transport of polycyclic aromatic hydrocarbons. J. Atmos Environ. 13, 45-53.

Black, C.A., Evans, D.D., White, J.L., Ensminger, L.E., and Clark, F.E. 1965. Methods of Soil Analysis. Part 2. Agron. Monogr. 9. ASA, Madison, WI.

Bossert, I., and Bartha, R. 1985. Plant growth in soil with a history of oil sludge disposal. J. Soil Sci. 140, 418-22.

Bremner, J.M., and Mulvaney, C.S. 1982. Nitrogen-total. In Methods of Soil Analysis. Part 2. pp 595-624 (Page, A.L., ed.). American Society of Agronomy, Madison, WI.

Cha neau, C.H., Morel, J.L., and Oudot, J. 1997. Phytotoxicity and plant uptake of fuel oil hydrocarbons. J. Environ. Qual. 26, 1478-1483.

Christopher, S.H., Marsden, P.J., and Sharleff, A.S. 1988. Evaluation of methods 3540 (Soxlet) and 3550 (Sonication) for evaluation of appendix IX analyses from solid samples. S-CUBED, Report for EPA contract 68-03-33-75, work assignment No.03, Document No. SSS-R-889436.

Crafts, A.S., and Reiber, H.G. 1948. Herbicidal properties of oils. J. Hilgardia. 18(2), 77-156.

Currier, H.B. 1951. Herbicidal properties of benzene and certain methyl derivatives. J. Hilgardia. 20(19), 383-406.

Fujikawa, K., Fort, F.L., Samejima, K., and Sakamoto, Y. 1993. Genotoxic potency in Drosophila melanogaster of selected aromatic amines and polycyclic aromatic hydrocarbons as assayed in the DNA repair test. J. Mutat Res. 290, 175-182.

Gao, Y.Z., and Zhu, L.Z. 2004. Plant uptake, accumulation and translocation of phenanthrene and pyrene in soils. Chemosphere 55, 1169-1178.

Gauvrit, C., and Cabanne, F. 1993. Oils for weed control: uses and mode of action. J. Pesticide Sci. 37, 147-153.

Gudin, C., and Syratt, W.J. 1975. Biological aspects of land rehabilitation following hydrocarbon contamination. J. Environ. Pollut. 8, 107-112.

Gunther, W.F., and Jones, G.E. 1988. Two stage mineralization of phenanthrene by estuarine enrichment cultures.J. Appl Environ Microbiol. 54, 929-936.

Haeseler, F., Blanchet, D., Druelle, V., Werner, P., and Vandecasteele, J.P. 1999. Ecotoxicological assessment of soils of former manufactured gas plant sites: bioremediation potential and pollutant mobility. J. Environ Sci Technol. 33(24), 4379-4384.

Harris, J.A., Birch, P., and Palmer, J. 1996. Land Restoration and Reclamation: Principles and Practice. Addison Wesley/Longman Ltd.

Henner, P., Schiavon, M., Druelle, V., and Lichtfouse, E. 1999. Phytotoxicity of ancient gaswork soils. Effect of polycyclic aromatic hydrocarbons (PAHs) on plant germination. J. Organic Geochem. 30, 963-969. 
Jian, Y., Wang, L., Peter, P.F., and Yu, H.T. 2004. Photomutagenicity of 16 polycyclic aromatic hydrocarbons from the US EPA priority pollutant list. Mutat. Res. 557, 99-108.

Joner, E.J., and Leyval, C. 2001. Influence of arbuscular mycorrhiza on clover and ryegrass grown together in a soil spiked with polycyclic aromatic hydrocarbons. J. Mycorrhiza. 10, 155-159.

Li, X., Feng, Y., and Sawatsky, N. 1997. Importance of soil water relations in assessing the endpoint of bioremediated soils. J. Plant and Soil. 192, 219-226.

Lindsay, W.L., and Norvell, W.A., 1978. Developement of a DTPA soil test for zinc, iron, manganese and copper. J. Am Soil Sci. Soc. 42, 421-428.

Maguire, J.D. 1962. Speed of germination: Aid in selection and evaluation of seedling emergence and vigor. J. Crop Sci. 2, 176-177.

Maila, M.P., and Cloete, T.E. 2002. Germination of Lepidium Sativum as a method to evaluate polycyclic aromatic hydrocarbons removals from contaminated soil. J. International Biodeterioration and Biodegradation. 50, 107-113.

Morehead, N.R., Eadie, B.J., Lake, B., Landrum, P.D., and Berner, D. 1986. The sorption of PAHs on to dissolved organic matter in Lake Michigan waters. Chemosphere. 15, 403-412.

Nelson, D.W., and Sommers L.E. 1982. Total carbon, organic carbon, and organic matter. In: Methods of Soil Analysis. Part 2. pp 539-579 (Page, A.L., ed.). American Society of Agronomy, Madison, WI.

Nicolotti, G., and Eglis, S., 1998. Soil contamination by crud oil: Impact on the mycorrihizosphere and on the vegetation potential of forest trees. J. Environ. Pollut. 99, 37-43.

Nylund, L., Heikkila, P., Hameila, M.P.L., Linnainmaa, K., and Sorsa, M. 1992. Genotoxic effects and chemical composition of four creosotes. J. Mutat Res. 265, 223-236.

Olsen, S.R., and Sommers, L.E. 1982. Phosphorus. In: Methods of Soil Analysis. Part 2. pp 403-431 (Page, A.L., ed.). American Society of Agronomy, Madison, WI.

Reilley, K.A., Banks, M.K., and Schwab, A.P. 1996. Dissipation of polycyclic aromatic hydrocarbons in the rhizosphere. J. Environ. Qual. 25, 212-219.

Ren, L., Zeiler, L.F., Dixon, G., and Greenberg, B.M. 1996. Photo induced effects of polycyclic aromatic hydrocarbons on Brassica napus (Canola) during germination and early seedling development. J. Ecotoxic. and Environ. Safety. 33, 73-80.

Rhoades, J.D. 1996. Salinity: Electrical conductivity and total dissolved solids. In: Methods of Soil Analysis. Part 2. pp 417-435. (Page, A.L., ed.). American Society of Agronomy, Madison, WI.

SAS Institute. 1988. SAS/STAT User's Guide. Release 6.03. SAS Institute, Cary, NC.

Siddiqui, S., and Adams, W.A. 2001. The fate of diesel hydrocarbons in soils and their effect on the germination of perennial ryegrass. J. Environ. Pollut. 118, 49-62.

Smreczak, B., and Maliszewska-Kordybach, B. 2003. Seeds germination and root growth of selected plants in PAHs contaminated soil.J. Fresenius Environ. Bulletin. 12, 946-949.

Terje, K. 1984. Effects of oil pollution on the germination and vegetative growth of five species of vascular plant. J. Oil Petroleum Pollute. 2, 25-30.

Thomas, G.W. 1996. Soil pH and soil acidity. In Methods of Soil Analysis. Part 2. pp 475-490 (Page, A.L., ed.). American Society of Agronomy, Madison, WI.

Warner, M.L., Sauer, R.H., and Carlile, D.W. 1983. Barley growth in coal liquid and diesel liquid fuels from coal and oil: a comparison of potential toxic effects on barley. J. Water, Air Soil Pollut. 22, 47-55. 